\title{
PEMISAHAN RENIUM-188 DARI SASARAN WOLFRAM-188 DENGAN METODE EKSTRAKSI MENGGUNAKAN PELARUT METIL ETIL KETON
}

\author{
Maria Christina P. ${ }^{1}$, Riftanio N. Hidayat ${ }^{1}$, Duyeh Setiawan ${ }^{2}$ \\ 1) Sekolah Tinggi Teknologi Nuklir - BATAN, Jl. Babarsari, PO BOX 6101/YKBB, \\ Yogyakarta 55281 Telp.: (0274)48085; Fax.: (0274)489715 \\ 2) Pusat Sains dan Teknologi Nuklir Terapan - BATAN, Jl. Tamansari No.71, Bandung \\ 40132
}

\begin{abstract}
ABSTRAK
PEMISAHAN RENIUM-188 DARI SASARAN WOLFRAM-188 DENGAN METODE EKSTRAKSI MENGGUNAKAN PELARUT METIL ETIL KETON. Pemisahan renium-188 dari sasaran wolfram-188 secara ekstraksi dilakukan untuk mengembangkan produksi radioisotop renium-188 yang memenuhi kemurnian secara radionuklida dan radiokimia. Pemisahan kedua unsur ini disimulasikan terhadap unsur yang tidak aktif untuk mengurangi risiko paparan radioaktif. Pemisahan renium dari wolfram ini menggunakan metode ekstraksi dengan pelarut metil etil keton (MEK). Parameter yang berpengaruh terhadap pemisahan ini ditentukan melalui kondisi optimum proses ekstraksi berdasarkan pengaruh waktu pengocokan, volume MEK, pH larutan, serta nilai koefisien distribusi. Penentuan konsentrasi renium dan wolfram hasil ekstraksi dilakukan dengan metode spektrofotometer UV-Vis dengan pengompleks KSCN dalam suasana asam dan pereduktor $\mathrm{SnCl}_{2}$. Hasil percobaan menunjukkan bahwa kondisi optimum proses ekstraksi dengan umpan masing-masing $10 \mathrm{ppm}$ yaitu pada waktu pengocokan selama 10 menit, volume MEK sebanyak $20 \mathrm{ml}$, dan kondisi larutan pada $\mathrm{pH}$ 5. Diperoleh konsentrasi maksimum renium yang terambil pada fase organik sebanyak 9,54 ppm dan nilai Kd sebesar 2,75, sementara Kd maksimum wolfram sebesar 0,08. Kondisi optimum proses ekstraksi ini selanjutnya dapat digunakan sebagai cara pemisahan renium dari wolfram yang radioaktif.
\end{abstract}

Kata kunci: koefisien distribusi, ekstraksi, renium, wolfram

\begin{abstract}
SEPARATION OF RHENIUM-188 FROM TUNGSTEN-188 AS A TARGET BY EXTRACTION METHOD USING SOLVENT METHYL ETHYL KETONE. Separation rhenium-188 from tungsten-188 as a target by extraction method has been done to develop production of rhenium-188 radioisotope that fulfills radionuclide and radiochemical purity. This separation determination was by solvent extraction using methyl ethyl ketone (MEK). Prior to the separation process, it was determined beforehand the optimum conditions of extraction process based on the effect of agitation time, the volume of MEK, the $p H$ of the solution, and distribution coefficient. Confirmation of the results of the extraction was conducted using UV-Vis spectrophotometer with a complexing KSCN under acidic conditions and $\mathrm{SnCl}_{2}$ as reductor. The results showed that the optimum condition for extraction process to feed each of 10 ppm was as follows: agitation time 10 minutes, volume of $M E K 20 \mathrm{ml}$, and the pH below 5. Maximum concentration of rhenium obtained at the organic phase was 9.5350 ppm. However, the condition of the extraction process did not affect the migration of tungsten to the organic phase. The maximum Dc value obtained was 2.7566 for rhenium and 0.0873 for tungsten. Optimum conditions of extraction process can be further tested on radioactive rhenium and tungsten as an alternative to the separation of radioisotopes.
\end{abstract}

Keywords: distribution coefficient, extraction, rhenium, and tungsten 


\section{PENDAHULUAN}

Teknologi produksi radioisotop dan radiofarmaka serta pemanfaatan operasi siklotron dan reaktor nuklir harus senantiasa ditingkatkan pengembangan dan pendayagunaannya agar dapat memenuhi kebutuhan pemakai. Pengembangan teknologi produksi radioisotop dan radiofarmaka diarahkan pada inovasi produk berdaya guna tinggi dan strategis sehingga dapat dimanfaatkan langsung dalam bidang kesehatan, industri, dan bidang-bidang lain.

Radioisotop dapat diperoleh melalui iradiasi neutron atau iradiasi partikel bermuatan. Iradiasi neutron dilakukan di dalam reaktor nuklir sebagai penghasil neutron. Iradiasi partikel bermuatan dilakukan di fasilitas siklotron. Pada proses iradiasi, bahan sasaran/target harus sesuai dan tahan terhadap kondisi iradiasi, misalnya tahan terhadap panas. Oleh karena itu, harus dilakukan pemilihan bentuk kimia sasaran. Pemilihan bentuk kimia sasaran ini juga perlu mempertimbangkan kemudahan proses pascairadiasi, misalnya kemudahan dalam pelarutan dan pemisahan. [2]

Dalam pembuatan radioisotop renium-188, dilakukan iradiasi terhadap sasaran wolfram alam sehingga menghasilkan wolfram-188 yang kemudian meluruh menjadi renium-188 dengan waktu luruh 69 hari. Renium-188 yang dihasilkan kemudian dipisahkan dari induknya, yaitu wolfram-188. Dalam berbagai penelitian untuk memperoleh produk radioisotop renium188 yang murni secara radiokimia dan radionuklida, telah dilakukan cara seperti pemisahan melalui kolom generator alumina [3] dan pemisahan secara elektrokimia [4]. Pada pemisahan melalui kolom generator alumina terdapat kelemahan, yaitu umpan yang dipisahkan harus memiliki aktivitas yang cukup besar karena kolom alumina memiliki daya serap sedikit sehingga umpan dengan aktivitas rendah sulit dipisahkan. Sementara itu, metode pemisahan secara elektrokimia masih belum memiliki prosedur yang pasti dalam proses pemisahannya. Oleh karena itu, diharapkan metode pemisahan secara ekstraksi dapat menjadi alternatif metode pemisahan yang mudah dan praktis.

Pada ekstraksi pemisahan W/Re ini, pelarut yang digunakan adalah metil etil keton (MEK). Penggunaan pelarut MEK ini merujuk pada penelitian pemisahan Tc terhadap sasaran induk Mo [7,8], kemudian diujicobakan terhadap renium, didasarkan pada kemiripan sifat kimia Tc dengan Re. Selain itu, pelarut MEK murah dan mudah didapatkan serta merupakan pelarut yang baik untuk proses ekstraksi renium. Pelarut MEK juga memiliki polaritas tinggi jika dibandingkan dengan pelarut lainnya karena memiliki ikatan rantai karbon lebih banyak dibandingkan senyawa lainnya seperti aseton, kloroform, dan lain-lain.

Beberapa faktor yang berpengaruh pada ekstraksi pemisahan renium dari wolfram adalah waktu pengocokan, volume pelarut organik, dan $\mathrm{pH}$ larutan. Peningkatan volume pelarut organik yang digunakan sangat penting karena akan mempengaruhi kenaikan koefisien distribusi renium di dalam pelarut organik. Namun, pelarut MEK tidak mempengaruhi kenaikan koefisien distribusi wolfram.

Dalam penelitian ini dipelajari pengaruh penambahan volume pelarut MEK, waktu pengocokan, serta $\mathrm{pH}$ larutan untuk proses ekstraksi terhadap koefisien distribusi (Kd) dengan tujuan untuk mengetahui tingkat keberhasilan dalam sistem pemisahan. Penelitian ini juga dilakukan terhadap renium dan wolfram yang tidak aktif, untuk mengurangi risiko paparan radiasi. Selanjutnya, kondisi optimum pemisahan digunakan untuk proses pemisahan renium dari wolfram yang radioaktif.

\section{DASAR TEORI}

\section{Produksi Radioisotop}

Radioisotop dapat diperoleh melalui iradiasi neutron atau iradiasi partikel bermuatan. Iradiasi neutron dilakukan di dalam reaktor nuklir sebagai penghasil neutron. Iradiasi partikel bermuatan dilakukan di fasilitas siklotron. Pada proses iradiasi, bahan sasaran/target harus sesuai dan tahan terhadap kondisi iradiasi, misalnya tahan terhadap panas. Oleh karena itu, harus dilakukan pemilihan bentuk kimia sasaran. Pemilihan bentuk kimia sasaran ini juga perlu mempertimbangkan kemudahan proses pascairadiasi, misalnya kemudahan dalam pelarutan dan pemisahan. [2]

\section{Radioisotop Renium-188}

Radioisotop renium-188 diproduksi melalui penembakan proton terhadap tungsten $\left({ }^{186} \mathrm{~W}\right)$ 
sebagai target, ${ }^{186} \mathrm{~W}(\mathrm{p}, \mathrm{n}){ }^{186} \mathrm{Re}$ atau ${ }^{186} \mathrm{~W}(\mathrm{~d}, 2 \mathrm{n}){ }^{186}$ Re. Karena perbedaan yang cukup besar menurut literatur, fungsi eksitasi reaksi di atas diukur kembali. Isotop ${ }^{188} \mathrm{Re}$ bersifat radioaktif dan digunakan untuk pengobatan kanker hati. Radioisotop tersebut memiliki kedalaman penetrasi jaringan sebesar $11 \mathrm{~mm}$ dan waktu paruh $17 \mathrm{jam} .{ }^{188} \mathrm{Re}$ juga digunakan dalam eksperimen pengobatan baru kanker pankreas, yang disampaikan melalui bakteri Listeria monocytogenes. [10\&11]

Berdasarkan tabel periodik, renium memiliki kesamaan dengan teknesium. Pekerjaan yang dilakukan untuk renium ke senyawa sasaran sering kali dapat dilakukan juga untuk teknesium. Hal ini berguna dalam radiofarmasi, karena sulit untuk bekerja dengan ${ }^{99 \mathrm{~m}} \mathrm{Tc}$ dalam pengobatan karena umur paruhnya yang pendek. [9]

\section{Kesetimbangan Sekuler}

Jika ada suatu radionuklida yang meluruh menjadi anak luruhnya, dan anak luruh tersebut bersifat radioaktif sehingga akan meluruh menjadi radionuklida berikutnya, peluruhan tersebut disebut peluruhan radioaktif berturutan.

Peluruhan wolfram-188 menjadi renium188 termasuk peluruhan sekuler. Hal ini karena waktu paruh induk wolfram sekitar 100 kali waktu paruh anak renium. Kesetimbangan sekuler terjadi jika umur paruh induk jauh lebih besar daripada umur paruh anak. Perbedaan antara umur paruh induk dan anak sekitar $10^{4}$ kali atau lebih besar. Karena umur paruh induk jauh lebih besar daripada umur paruh anak, maka konstanta peluruhan induk jauh lebih besar daripada konstanta peluruhan anak. Akibatnya:

$$
\lambda_{2}-\lambda_{1} \approx \lambda_{2} \text { dan } e^{-\lambda_{2} t}
$$

Aktivitas

$$
A_{t}=N \cdot \Phi \cdot \sigma\left(1-e^{-0,693 t / T}\right)
$$

sehingga,

$$
\begin{aligned}
& N_{2}=\frac{\lambda_{1}}{\lambda_{2}} N_{1}^{0} e^{-\lambda_{1} t} \\
& N_{2} \cdot \lambda_{2}=\lambda_{1} N_{1}^{0} e^{-\lambda_{1} t} \\
& N_{2} \cdot \lambda_{2}=N_{1} . . \lambda_{1}
\end{aligned}
$$

Pada hari pertama,

$$
N_{\text {anak }_{1}}=\frac{\lambda_{1}}{\lambda_{2}-\lambda_{1}} N_{i n d u k_{0}}^{0} e^{-\lambda_{1} t}
$$

Untuk hari selanjutnya,

$$
N_{\text {anak }}=\frac{\lambda_{1}}{\lambda_{2}-\lambda_{1}} N_{a n a k_{1}}^{0} e^{-\lambda_{1} t}
$$

sehingga,

$N_{\text {anak }_{n+1}}=\frac{\lambda_{1}}{\lambda_{2}-\lambda_{1}} N_{\text {anak }_{n-1}}^{0} e^{-\lambda}$

Menentukan $\mathrm{T}_{\max }$,

$$
T_{\max }=\frac{1}{\lambda_{2}-\lambda_{1}} \ln \frac{\lambda_{2}}{\lambda_{1}}
$$

Pada kesetimbangan sekuler, aktivitas anak akan sama dengan aktivitas induk. Radionuklida anak akan meluruh dengan umur paruh radionuklida induk. [5] 


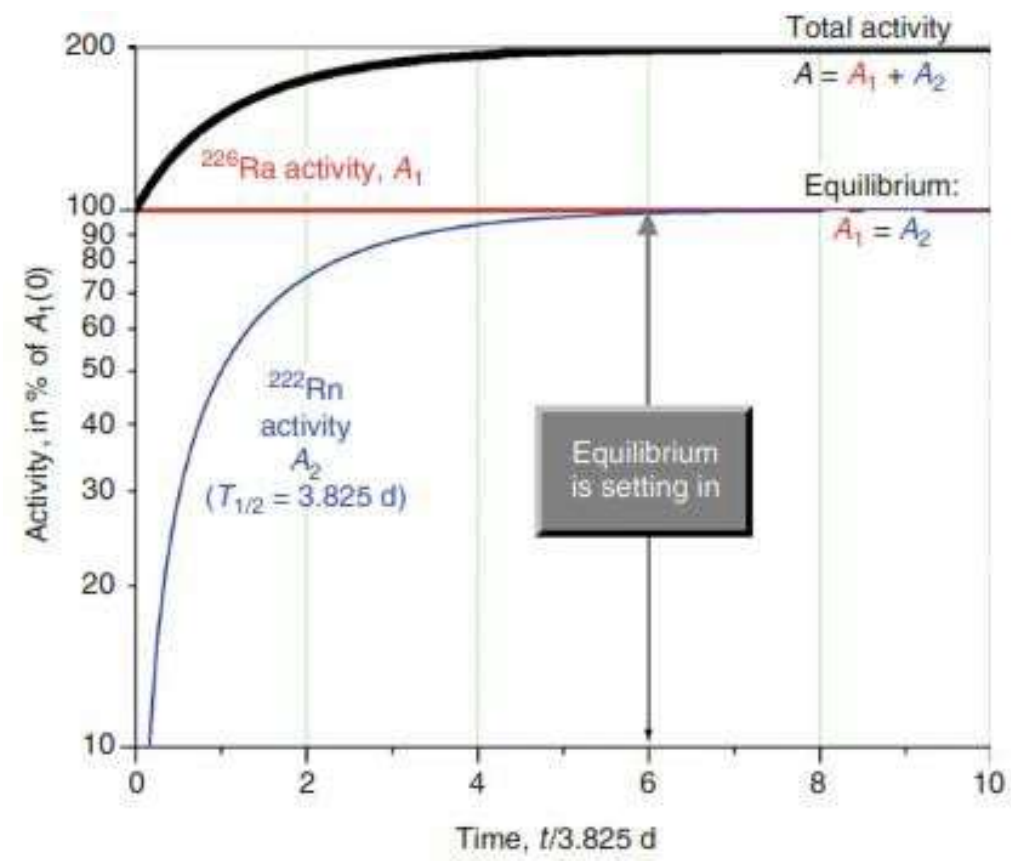

Gambar 1. Skema Kesetimbangan Sekuler [5]

Persyaratan Radioisotop Berdasarkan IAEA

Radioisotop yang telah diproduksi di dalam reaktor nuklir selanjutnya perlu diperiksa kualitasnya untuk memastikan bahwa radioisotop yang dihasilkan tersebut memiliki spesifikasi yang memenuhi ketentuan yang ditetapkan oleh IAEA. Spesifikasi larutan radioisotop renium yang ditetapkan IAEA adalah sebagai berikut. [1]

1. Senyawa berupa larutan dalam bentuk natrium perenat $\left(\mathrm{NaReO}_{4}\right)$.

2. Larutan radioisotop harus bersih, tanpa pengotor yang dapat terlihat, dan berfasa air.

3. Larutan radioisotop berwarna sedikit kekuningan.

4. $\mathrm{pH}$ larutan radioisotop dijaga supaya berkisar di antara 2,5-5,0.

5. Kemurnian radiokimia radioisotop lebih besar atau sama dengan $98 \%$.

6. Kemurnian radionuklida radioisotop sebesar 99,9\%.

\section{Ekstraksi Cair-Cair}

Ekstraksi cair-cair merupakan suatu teknik di mana suatu larutan (biasanya dalam air) dibuat bersentuhan dengan suatu pelarut kedua (biasanya organik), yang pada hakikatnya tak bercampur dengan larutan pertama, sehingga satu atau lebih zat terlarut (solute) dari larutan pertama berpindah ke dalam pelarut kedua.
Pemisahan dengan cara ini bersifat sederhana, bersih, cepat, dan mudah. Dalam banyak kasus, pemisahan dapat dilakukan dengan mengocok kedua larutan dalam sebuah corong pisah selama beberapa menit. Teknik ini dapat diterapkan untuk bahan-bahan dari tingkat runutan maupun yang dalam jumlah banyak.

Untuk memahami prinsip-prinsip dasar ekstraksi, terlebih dulu harus dibahas berbagai istilah yang digunakan untuk menyatakan keefektifan pemisahan. Untuk suatu zat terlarut A yang didistribusikan antara dua fase tak tercampurkan $a$ dan $b$, hukum distribusi (atau partisi) Nernst menyatakan bahwa asal keadaan molekulnya sama dalam kedua cairan dan temperaturnya konstan, maka:

$\frac{\text { Kons.zat terlarut pelarut } A}{\text { Kons.zat terlarut pelarut } B}=K_{D}$

$\mathrm{K}_{\mathrm{D}}$ merupakan sebuah tetapan, yang dikenal sebagai koefisien distribusi (atau koefisien partisi). Hukum ini, seperti dinyatakan di atas, secara termodinamis tidak benar-benar tepat (misalnya, tak diperhitungkan aktivitas dari berbagai spesi itu dan karenanya diharapkan hanya akan berlaku dalam larutan encer di mana angka banding aktivitas mendekati 1), tetapi merupakan suatu pendekatan yang berguna. Hukum ini, dalam bentuknya yang sederhana, tak berlaku bila spesi yang didistribusikan mengalami disosiasi atau asosiasi dalam salah satu fase tersebut. [5] 


\section{METODE}

\section{Penyiapan Larutan Induk Standar}

Larutan induk wolfram $1000 \mathrm{mg} / \mathrm{l}$ dibuat dengan cara menimbang $\mathrm{WO}_{3}$ sebanyak 0,1262 g, lalu dilarutkan dalam $\mathrm{NaOH} 2 \mathrm{~N}$, kemudian diencerkan hingga volume akhir $100 \mathrm{ml}$. Selanjutnya dibuat larutan induk renium berkadar $200 \mathrm{ppm}$ dengan menimbang logam renium sebanyak $0,01 \mathrm{~g}$ dan dilarutkan dalam peroksida, kemudian diuapkan hingga kisat. Selanjutnya, residu dilarutkan dalam $\mathrm{NaCl}$ $0,9 \%$ dan diencerkan hingga volume akhir 100 $\mathrm{ml}$.

\section{Variasi Waktu Pengocokan Ekstraksi}

Diambil larutan wolfram berkadar $10 \mathrm{ppm}$ sebanyak $25 \mathrm{ml}$. Larutan tersebut diekstraksi menggunakan MEK dalam corong pisah selama 5 menit, dengan perbandingan fase air dengan fase organik 5:1. Setelah diekstraksi, fase air dan fase organik dipisahkan. Kadar masing-masing fase dianalisis dengan spektrofotometri UV-Vis. Ekstraksi diulang untuk lama waktu yang berbeda, yaitu 10, 15, 20,25 , dan 30 menit. Hal yang sama dilakukan pada larutan induk renium.

\section{Variasi Penambahan Volume Pelarut MEK}

Diambil larutan wolfram berkadar $10 \mathrm{ppm}$ sebanyak $25 \mathrm{ml}$. Larutan tersebut diekstraksi dalam corong pisah dengan menggunakan MEK, selama 10 menit, dengan volume $5 \mathrm{ml}$. Setelah diekstraksi, fase air dan fase organik dipisahkan. Kadar masing-masing fase dianalisis dengan spektrofotometri UV-Vis. Ekstraksi diulang pada volume pelarut yang berbeda, yaitu 7,$5 ; 10 ; 12,5 ; 15 ; 17,5 ;$ dan 20 $\mathrm{ml}$. Hal yang sama dilakukan pada larutan induk renium.

\section{Variasi Pengaturan pH}

Diambil larutan wolfram berkadar10 ppm sebanyak $25 \mathrm{ml} . \mathrm{pH}$ larutan diatur pada $\mathrm{pH} 3$. Larutan tersebut diekstraksi dalam corong pisah dengan menggunakan MEK selama 10 menit dengan volume 17,5 $\mathrm{ml}$. Setelah diekstraksi, fase air dan fase organik dipisahkan. Kadar masing-masing fase dianalisis dengan spektrofotometri UV-Vis. Ekstraksi diulang dengan mengatur $\mathrm{pH}$ larutan yang berbeda, yaitu $3,4,5,6,7$, dan 8 . Hal yang sama dilakukan pada larutan induk renium.

\section{Analisis}

Analisis wolfram dan renium dilakukan dengan menggunakan spektrofotometer UV-Vis. Sebelum dilakukan pengukuran absorban, panjang gelombang diatur terlebih dulu, untuk wolfram pada $403 \mathrm{~nm}$ dan renium pada 420 nm. Sebagai larutan pengompleks digunakan KSCN $30 \%$ dalam suasana asam, dengan reduktor $\mathrm{SnCl}_{2} 30 \%$. Selanjutnya, masingmasing cuplikan diukur absorbansinya dengan spektrofotometer UV-Vis. Kemudian dapat ditentukan kadar $\mathrm{W}$ dan Re pada setiap variasi.

Besarnya koefisien distribusi (Kd) dapat dinyatakan sebagai berikut.

$K_{D}=\frac{C_{\text {org }}}{C_{\text {air }}}$

$\mathrm{C}_{\text {org }}=$ konsentrasi unsur dalam organik

$\mathrm{C}_{\mathrm{air}}=$ konsentrasi unsur dalam fase air

\section{HASIL DAN PEMBAHASAN}

\section{Variasi Waktu Pengocokan Ekstraksi}

Berdasarkan Tabel 1 serta Gambar 2 dan 3, tampak bahwa semakin lama waktu ekstraksi, Re yang terekstraksi ke dalam fase organik semakin besar. Kenaikan ini akan mencapai maksimum saat tercapai waktu kesetimbangan, yaitu jika konsentrasi Re yang terdistribusi dari fase air ke fase organik sama dengan konsentrasi $\operatorname{Re}$ yang terdistribusi dari fase organik ke fase air. Pada wolfram, tidak terjadi distribusi yang signifikan terhadap waktu pengocokan dan masih banyak yang tertinggal pada fase air. 
Tabel 1. Waktu Pengocokan Ekstraksi Wolfram dan Renium pada Kondisi Umpan Campuran Konsentrasi Masing-Masing 10 ppm, Volume MEK 5 ml

\begin{tabular}{|c|c|c|c|c|c|}
\hline Variasi & Unsur & Fase & Absorban & Kadar (ppm) & Deviasi (S) \\
\hline \multirow{3}{*}{5 Menit } & \multirow{2}{*}{ Renium } & Cair & 0,336 & 8,455 & \multirow{2}{*}{0,0017} \\
\hline & & Organik & 0,082 & 1,54 & \\
\hline & Wolfram & Cair & 0,814 & 9,2183 & 0,0136 \\
\hline \multirow{3}{*}{10 Menit } & \multirow{2}{*}{ Renium } & Cair & 0,329 & 8,265 & \multirow{2}{*}{0,0282} \\
\hline & & Organik & 0,089 & 1,728 & \\
\hline & Wolfram & Cair & 0,8 & 9,109 & 0,0137 \\
\hline \multirow{3}{*}{15 Menit } & \multirow{2}{*}{ Renium } & Cair & 0,328 & 8,264 & \multirow{2}{*}{0,0225} \\
\hline & & Organik & 0,089 & 1,723 & \\
\hline & Wolfram & Cair & 0,812 & 9,204 & 0,0085 \\
\hline \multirow{3}{*}{20 Menit } & \multirow{2}{*}{ Renium } & Cair & 0,329 & 8,266 & \multirow{2}{*}{0,0431} \\
\hline & & Organik & 0,089 & 1,7186 & \\
\hline & Wolfram & Cair & 0,812 & 9,2 & 0,0137 \\
\hline \multirow{3}{*}{25 Menit } & \multirow{2}{*}{ Renium } & Cair & 0,328 & 8,263 & \multirow{2}{*}{0,0337} \\
\hline & & Organik & 0,089 & 1,7013 & \\
\hline & Wolfram & Cair & 0,812 & 9,1957 & 0,0163 \\
\hline \multirow{3}{*}{30 Menit } & \multirow{2}{*}{ Renium } & Cair & 0,328 & 8,27 & \multirow{2}{*}{0,0277} \\
\hline & & Organik & 0,089 & 1,7263 & \\
\hline & Wolfram & Cair & 0,915 & 9,211 & 0,0144 \\
\hline
\end{tabular}

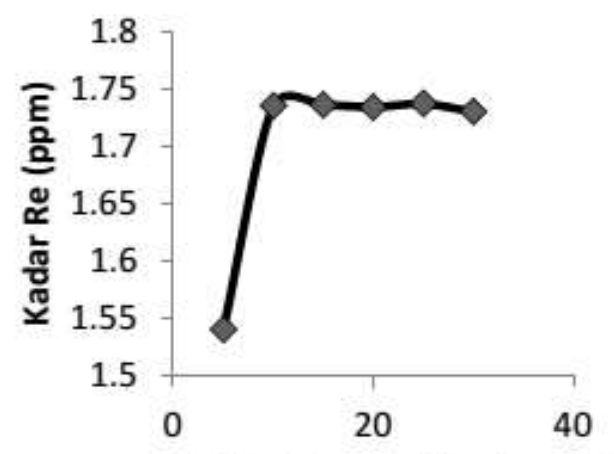

Waktu Pengocokan (menit)

Gambar 2. Pengaruh Waktu Pengocokan terhadap Kadar Re dalam Fase Organik

Gambar 2 menunjukkan bahwa setelah ekstraksi berlangsung selama 10 menit, dengan bertambahnya waktu ekstraksi, maka Re yang masuk ke dalam fase organik relatif tetap. Berdasarkan hal ini, dapat dikatakan bahwa waktu kesetimbangan sudah tercapai. Jadi untuk selanjutnya, ekstraksi dilakukan selama 10 menit.

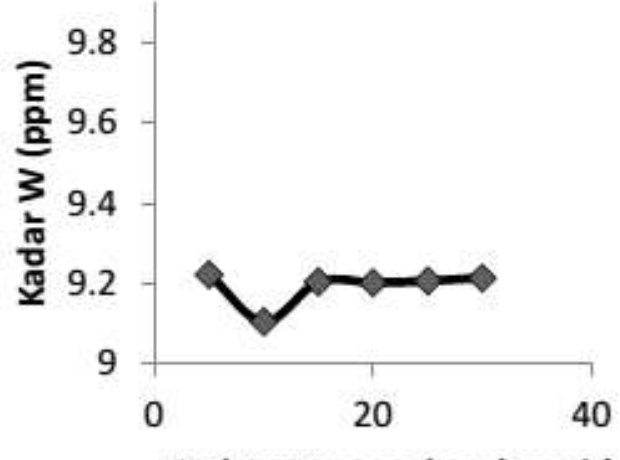

Gambar 3. Pengaruh Waktu Pengocokan terhadap Kadar W dalam Fase Air

\section{Variasi Penambahan Volume Pelarut MEK}

Pengaruh penambahan volume pelarut MEK disajikan dalam Tabel 2 serta Gambar 4 dan 5. Dengan bertambahnya volume pelarut, renium yang terekstraksi dalam fase organik semakin besar. Penambahan volume ini dilakukan hingga renium terbawa seluruhnya atau sampai pada kondisi kesetimbangan pelarut membawa renium pada fase organik. 
Tabel 2. Volume Pelarut MEK pada Proses Ekstraksi pada Kondisi Umpan Campuran Konsentrasi Masing-Masing 10 ppm

\begin{tabular}{|c|c|c|c|c|c|}
\hline Variasi & Unsur & Fase & Absorban & Kadar (ppm) & Deviasi (S) \\
\hline \multirow{3}{*}{$5 \mathrm{~mL}$} & \multirow{2}{*}{ Renium } & Cair & 0,329 & 8,265 & \multirow{2}{*}{0,0017} \\
\hline & & Organik & 0,089 & 1,538 & \\
\hline & Wolfram & Cair & 0,8 & 9,2183 & 0,0136 \\
\hline \multirow{3}{*}{$7,5 \mathrm{~mL}$} & \multirow{2}{*}{ Renium } & Cair & 0,286 & 7,104 & \multirow{2}{*}{0,0417} \\
\hline & & Organik & 0,132 & 2,8873 & \\
\hline & Wolfram & Cair & 0,81 & 9,2086 & 0,0222 \\
\hline \multirow{3}{*}{$10 \mathrm{~mL}$} & \multirow{2}{*}{ Renium } & Cair & 0,215 & 5,167 & \multirow{2}{*}{0,042} \\
\hline & & Organik & 0,203 & 4,8223 & \\
\hline & Wolfram & Cair & 0,815 & 9,2326 & 0,0055 \\
\hline \multirow{3}{*}{$12,5 \mathrm{~mL}$} & \multirow{2}{*}{ Renium } & Cair & 0,157 & 3,577 & \multirow{2}{*}{0,0545} \\
\hline & & Organik & 0,261 & 6,4656 & \\
\hline & Wolfram & Cair & 0,813 & 9,206 & 0,0052 \\
\hline \multirow{3}{*}{$15 \mathrm{~mL}$} & \multirow{2}{*}{ Renium } & Cair & 0,075 & 1,343 & \multirow{2}{*}{0,027} \\
\hline & & Organik & 0,342 & 8,591 & \\
\hline & Wolfram & Cair & 0,811 & 9,2213 & 0,0086 \\
\hline \multirow{3}{*}{$17,5 \mathrm{~mL}$} & \multirow{2}{*}{ Renium } & Cair & 0,045 & 0,525 & \multirow{2}{*}{0,0562} \\
\hline & & Organik & 0,372 & 9,481 & \\
\hline & Wolfram & Cair & 0,811 & 9,227 & 0,0035 \\
\hline \multirow{3}{*}{$20 \mathrm{~mL}$} & \multirow{2}{*}{ Renium } & Cair & 0,042 & 0,444 & \multirow{2}{*}{0,0418} \\
\hline & & Organik & 0,376 & 9,5357 & \\
\hline & Wolfram & Cair & 0,813 & 9,209 & 0,0052 \\
\hline
\end{tabular}

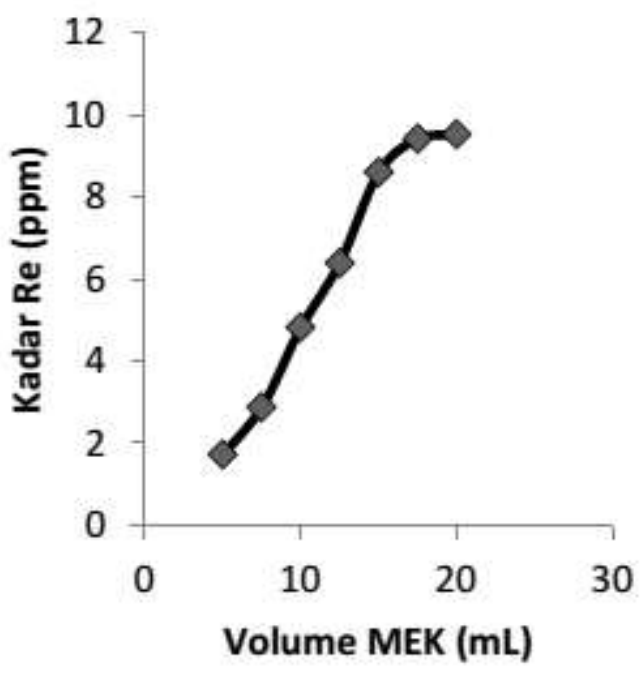

Gambar 4. Pengaruh Volume Pelarut MEK terhadap Kadar Re dalam Fase Organik

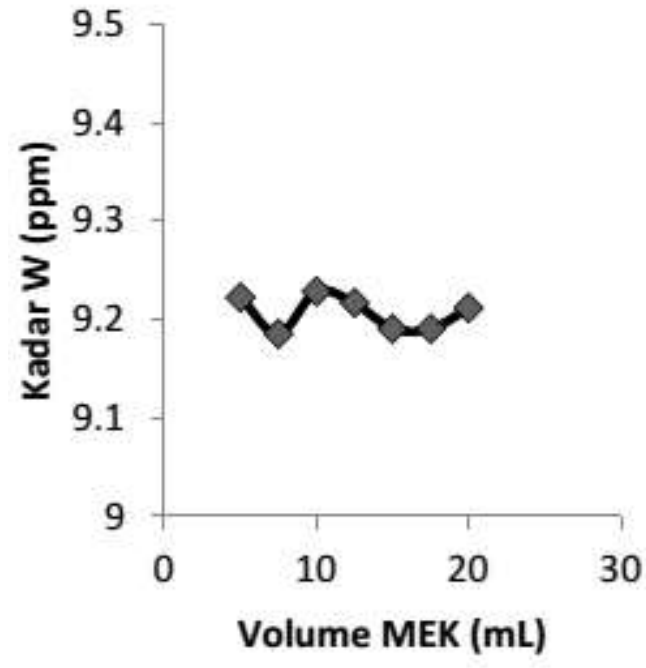

Gambar 5. Pengaruh Volume Pelarut MEK terhadap Kadar W dalam Fase Air

Dalam Gambar 4, setelah penambahan volume pelarut MEK pada volume $17,5 \mathrm{ml}$, tampak bahwa dengan bertambahnya volume pelarut MEK, Re yang masuk ke dalam fase organik relatif tetap. Hal tersebut menandakan jumlah Re yang terbawa dapat dikatakan sudah mencapai tingkat maksimum. Dalam hal ini Re yang terbawa pada fase organik saat penambahan $20 \mathrm{ml}$ pelarut MEK mencapai maksimum pada 9,545 ppm. Namun, hal ini tidak terjadi pada wolfram, yang tidak terpengaruh oleh penambahan volume pelarut 
MEK. Konsentrasi wolfram yang terdapat pada fase air berkisar pada 9,2 ppm. Hal ini disebabkan oleh nilai Kd wolfram yang sebesar 0,08. Apabila dikaitkan dengan Persamaan (9), berapa pun jumlah solvent yang ditambahkan pada proses ekstraksi, karena nilai Kd wolfram sangat kecil maka jumlah wolfram yang bermigrasi ke fase organik tetap tidak akan banyak.

\section{Variasi Pengaturan pH}

Pengaturan $\mathrm{pH}$ larutan dilakukan untuk mengetahui distribusi perpindahan renium atau wolfram ke dalam fase organik serta mengamati perpindahan yang paling besar pada $\mathrm{pH}$ tertentu. Tabel 3 serta Gambar 6 dan 7 menyajikan pengaruh pengaturan $\mathrm{pH}$ larutan pada proses distribusi renium dan wolfram ke dalam fase organik.

Tabel 3. pH Larutan MEK pada Proses Ekstraksi dengan Kondisi Umpan Campuran Konsentrasi MasingMasing 10 ppm

\begin{tabular}{|c|c|c|c|c|c|}
\hline Variasi (pH) & Unsur & Fase & Absorban & Kadar (ppm) & Deviasi (S) \\
\hline \multirow{3}{*}{3} & \multirow{2}{*}{ Renium } & Cair & 0,123 & 0,6903 & \multirow{2}{*}{0,0465} \\
\hline & & Organik & 0,124 & 9,3097 & \\
\hline & Wolfram & Cair & 0,811 & 9,2183 & 0,0115 \\
\hline \multirow{3}{*}{4} & \multirow{2}{*}{ Renium } & Cair & 0,124 & 0,6663 & \multirow{2}{*}{0,0549} \\
\hline & & Organik & 0,089 & 9,3337 & \\
\hline & Wolfram & Cair & 0,811 & 9,109 & 0,0116 \\
\hline \multirow{3}{*}{5} & \multirow{2}{*}{ Renium } & Cair & 0,124 & 0,655 & \multirow{2}{*}{0,0173} \\
\hline & & Organik & 0,089 & 9,345 & \\
\hline & Wolfram & Cair & 0,812 & 9,204 & 0,0139 \\
\hline \multirow{3}{*}{6} & \multirow{2}{*}{ Renium } & Cair & 0,124 & 0,6963 & \multirow{2}{*}{0,0419} \\
\hline & & Organik & 0,089 & 9,3037 & \\
\hline & Wolfram & Cair & 0,813 & 9,2 & 0,007 \\
\hline \multirow{3}{*}{7} & \multirow{2}{*}{ Renium } & Cair & 0,124 & 0,6673 & \multirow{2}{*}{0,0092} \\
\hline & & Organik & 0,089 & 9,3327 & \\
\hline & Wolfram & Cair & 0,901 & 9,1957 & 0,0438 \\
\hline \multirow{3}{*}{8} & \multirow{2}{*}{ Renium } & Cair & 0,1242 & 0,67 & \multirow{2}{*}{0,056} \\
\hline & & Organik & 0,089 & 9,33 & \\
\hline & Wolfram & Cair & 0,811 & 9,211 & 0,0068 \\
\hline
\end{tabular}

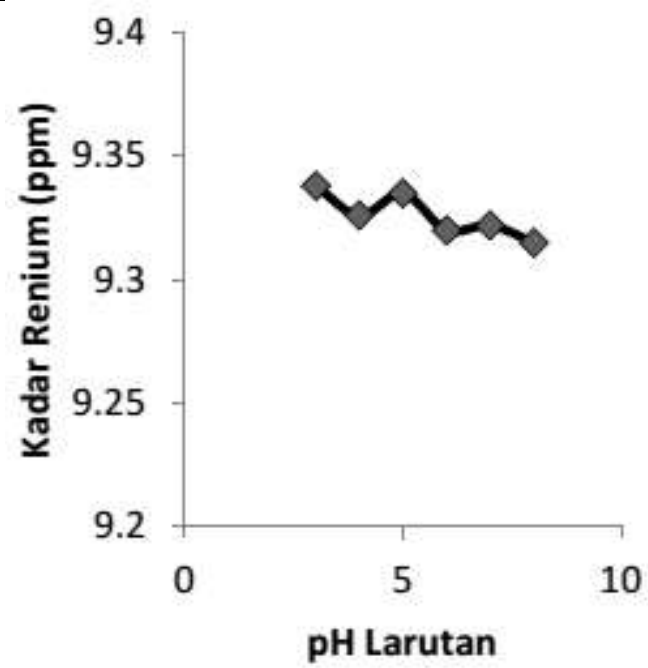

Gambar 6. Pengaruh pH larutan terhadap kadar Re dalam fase organik.

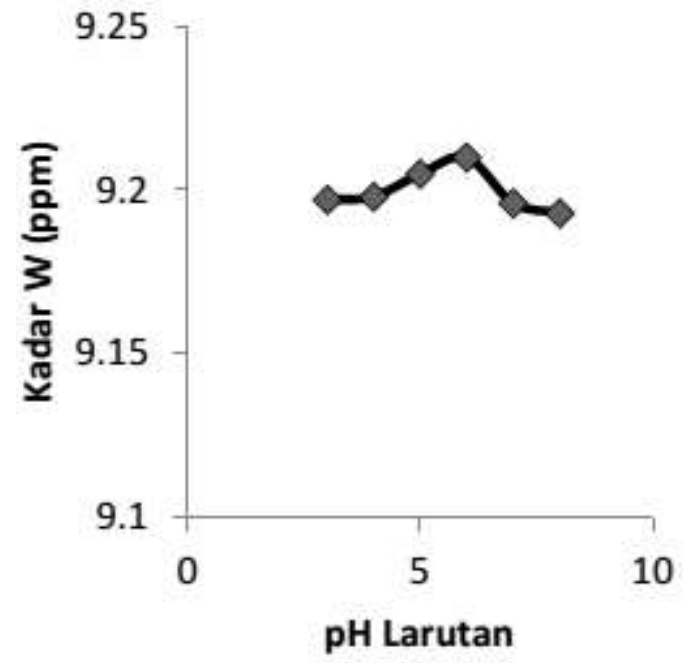

Gambar 7. Pengaruh pH larutan terhadap Kadar W dalam Fase Air 
Berdasarkan Gambar 6 dan Gambar 7 yang ditunjukkan di atas, terlihat bahwa semakin $\mathrm{pH}$ ditingkatkan, jumlah kadar $\mathrm{Re}$ yang terambil ke dalam fase organik semakin menurun, namun tidak terlalu signifikan. Oleh karena itu, kondisi ekstraksi dilakukan pada $\mathrm{pH}$ di bawah 5. Sementara pada wolfram, peningkatan $\mathrm{pH}$ tidak berpengaruh terhadap distribusi $\mathrm{W}$ ke dalam fase organik dan relatif dominan pada fase air pada kisaran mendekati 9,2 ppm. pH 6 merupakan titik tertinggi jumlah wolfram yang tertinggal dalam fase air.

\section{Penentuan Koefisien Distribusi pada Kondisi Optimum}

Koefisien distribusi (Kd) dilakukan untuk mengetahui perbandingan $\mathrm{Kd}$ renium dengan Kd wolfram. Pada penelitian ini, radioisotop yang diinginkan adalah renium. Oleh karena itu, diharapkan Kd renium lebih besar daripada Kd wolfram.

Berdasarkan data yang diperoleh, koefisien distribusi renium dan wolfram dihitung dari proses ekstraksi yang dilakukan dengan kondisi optimum pada waktu pengocokan 10 menit, volume pelarut $20 \mathrm{ml}$, serta $\mathrm{pH}$ larutan diatur agar berada di bawah 5 . Tabel 4 dan 5 menyajikan data koefisien distribusi renium dan wolfram.

Tabel 4. Koefisien Distribusi Renium dengan Variasi Waktu Pengocokan 10 Menit, Volume MEK 20 ml, dan pH Larutan di Bawah 5

\begin{tabular}{cccc}
\hline \multicolumn{4}{c}{ Renium } \\
\cline { 1 - 2 } & \multicolumn{2}{c}{ Fase Air } & Fase Organik \\
\cline { 2 - 3 } pH & \multicolumn{2}{c}{ Kd } \\
\cline { 2 - 3 } & \multicolumn{1}{c}{ Kons. (ppm) } & Kons. (ppm) & \\
\hline 3 & $0,69 \pm 0,05$ & $9,31 \pm 0,04$ & 13,48 \\
4 & $0,69 \pm 0,05$ & $9,34 \pm 0,05$ & 14,08 \\
5 & $0,69 \pm 0,02$ & $9,34 \pm 0,02$ & 14,05
\end{tabular}

Tabel 5. Koefisien Distribusi Wolfram dengan Variasi Waktu Pengocokan 10 Menit, Volume MEK $20 \mathrm{ml}$, dan $\mathrm{pH}$ Larutan di Bawah 5

\begin{tabular}{cccc}
\hline \multicolumn{4}{c}{ Wolfram } \\
& \multicolumn{2}{c}{ Fase Air } & Fase Organik \\
\cline { 2 - 2 } pH & Kd \\
\cline { 2 - 3 } & Kons. (ppm) & Kons. (ppm) & \\
\hline 3 & $9,19 \pm 0,01$ & $0,80 \pm 0,01$ & 0,087 \\
4 & $9,21 \pm 0,01$ & $0,80 \pm 0,01$ & 0,087 \\
5 & $9,21 \pm 0,01$ & $0,79 \pm 0,01$ & 0,086
\end{tabular}

Dari data yang ditunjukkan oleh Tabel 4 dan 5, dapat dilihat bahwa Kd renium lebih besar daripada $\mathrm{Kd}$ wolfram. Hal ini dipengaruhi oleh afinitas elektron kedua unsur tersebut. Afinitas renium lebih besar daripada afinitas wolfram karena dalam sistem periodik unsur, posisi renium terletak lebih di sebelah kanan daripada wolfram. Pada proses ekstraksi, pelarut MEK lebih kuat menarik renium yang memiliki afinitas lebih besar.

\section{Simulasi Pemisahan Renium-188 Terhadap Target Wolfram-188}

Dengan menggunakan Persamaan (2) aktivitas wolfram saat selesai diiradiasi didapat sebesar $760,77 \mathrm{mCi}$ dan $\mathrm{T}_{\max }$ aktivitas induk wolfram dengan anak renium 4,73 hari. Selanjutnya, jumlah renium yang dihasilkan dari peluruhan renium ditentukan dengan menggunakan Persamaan (4), (5), dan (6).

Penentuan jumlah renium yang dihasilkan dibatasi hanya sampai 100 hari. Hasil yang diperoleh ditunjukkan pada Gambar 8 .

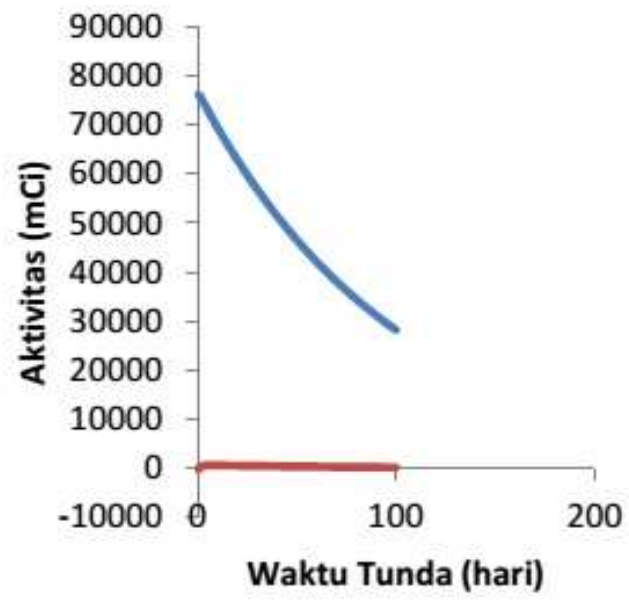

Gambar 8. Peluruhan antara Induk Wolfram dengan Anak Renium

Berdasarkan Gambar 8, dapat dilihat bahwa laju peluruhan anak (renium) tidak terlihat signifikan dibandingkan dengan induknya. Hal ini dikarenakan perbedaan yang cukup jauh antara waktu paruh induk (wolfram) dengan waktu paruh anak (renium). Oleh karena itu, laju peluruhan anak (renium) dapat diperjelas kembali, seperti yang ditunjukkan pada Gambar 9. 


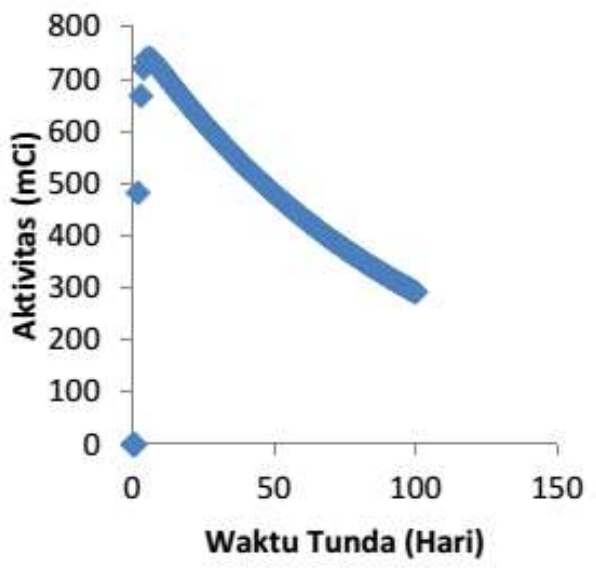

Gambar 9. Peluruhan Anak Renium

Tabel data peluruhan induk (wolfram) dan anak (renium) memperlihatkan bahwa renium yang dihasilkan setiap hari hanya dalam jumlah yang cukup kecil. Dengan demikian, dapat dikatakan bahwa satu gram wolfram yang diiradiasi, tidak sepenuhnya meluruh menjadi renium. Renium dapat terus diambil setiap hari hingga aktivitas wolfram menjadi sangat kecil.

Berdasarkan perolehan pada kondisi optimum, jumlah maksimum renium yang terambil sebanyak 95,57\%. Dari data ini dapat dikatakan kondisi pemisahan secara ekstraksi masih belum memenuhi ketentuan yang ditetapkan oleh IAEA, yakni $\geq 98 \%$. Oleh karena itu, perlu dilakukan beberapa modifikasi terhadap proses ekstraksi yang dilakukan, seperti melakukan variasi kecepatan pengocokan agar jumlah renium yang terambil dapat ditingkatkan kembali.

Selain itu, jika proses ekstraksi dilakukan dengan bahan radioaktif, ditinjau dari segi keselamatan cukup berisiko tinggi terhadap paparan radioaktif yang akan didapat karena proses ekstraksi dilakukan hanya menggunakan peralatan corong pisah sederhana. Risiko terjadinya kontaminasi oleh radioaktif juga cukup tinggi sekalipun proses pemisahan dilakukan dalam fasilitas glove box. Oleh karena itu, selanjutnya perlu dilakukan penelitian mengenai konstruksi alat ekstraksi yang aman dan memenuhi standar keselamatan. Dengan kata lain, konstruksi proses ekstraksi yang dilakukan belum memenuhi standar keselamatan yang ditetapkan apabila dibandingkan dengan pemisahan dengan metode lain, seperti menggunakan kolom generator.

\section{KESIMPULAN}

Berdasarkan penelitian pemisahan renium-188 dari sasaran wolfram-188 menggunakan metode ekstraksi dengan pelarut metil etil keton, dapat disimpulkan sebagai berikut.

1. Proses pemisahan renium dari wolfram dapat dilakukan dengan menggunakan ekstraktan MEK dengan waktu pengocokan 10 menit.

2. Pelarut metil etil keton yang ditambahkan mencapai maksimum pada penambahan 20 $\mathrm{ml}$, dengan umpan $10 \mathrm{ppm}$.

3. Makin tinggi $\mathrm{pH}$ larutan, renium yang terambil semakin berkurang. $\mathrm{pH}$ larutan diatur pada kisaran di bawah 5 .

4. Koefisien distribusi renium lebih besar, yaitu 14,08, daripada koefisien distribusi wolfram yang berkisar pada 0,08 .

\section{SARAN}

1. Penetapan jadwal waktu iradiasi seharusnya tidak mundur.

2. Penelitian perlu diujicobakan pada wolfram dan renium radioaktif.

\section{DAFTAR PUSTAKA}

1. Mirzadeh, S., F.F. Knapp Jr., and A.P. Callahan, 2003. Manual for Reactor Produced Radioisotopes. International Atomic Energy Agency.

2. PDIN-BATAN, $1998 . \quad$ Atomos: Radioisotop dan Radiofarmaka untuk Bidang Kesehatan, Pertanian, Hidrologi, dan Industri. Jakarta: Pusat Diseminasi IPTEK Nuklir.

3. Sriyono, H. Lubis, E. Sarmini, Herlina, dan I. Saptiama, 2013. Pemisahan Radioisotop ${ }^{188}$ Re dari Radioisotop ${ }^{188} \mathrm{~W}$ Melalui Generator ${ }^{188} \mathrm{~W} /{ }^{188} \mathrm{Re}$ Berbasis Alumina. Serpong: Pusat Radioisotop dan Radiofarmaka.

4. Chakravarty, R., A. Dash, K. Kothari, M.R. Ambikalmajan Pillai, and M. Venkatesh. 2008. A Novel ${ }^{188} \mathrm{~W}^{188} \mathrm{Re}$ Electrochemical Generator with Potential for Medical Applications. Mumbai: Atomic Research Centre.

5. Vertes, A., S. Nagy, Z. Klencsar, R.G. Lovas, and F. Rosch, 2011. "Kinetics of Radioactive Decay." In: S. Nagy, Handbook of Nuclear Chemistry (p. 347). Budapest: Springer. 
6. Baset, .J, R.C. Denney, G.H. Jeffrey, and J. Mendhan, 1994. Buku Ajar Vogel: Kimia Analisis Kuantitatif Bab VI Ekstraksi Pelarut. Alih bahasa oleh Pudjaatmaka, A. Hadyana, L. Setiono. Jakarta: Penerbit Buku Kedokteran EGC.

7. Yono, S., Abidin, Herlina, Sulaiman, Sriyono, Hambali, dan H.G. Adang, 2011. Pemekatan Larutan Teknesium- 99m Hasil Ekstraksi dengan Adsorpsi Resin dan Evaporasi Tekanan Rendah. Serpong: Pusat Radioisotop dan Radiofarmaka.

8. Awaludin, R., H. Lubis, Sriyono, Abidin, Herlina, dan A. Hardi, 2012. Ekstraksi Teknesium-99m dari Larutan Molibdenum Skala Besar. dalam: Seminar Nasional VIII SDM Teknologi Nuklir.

9. Deutsch, E., K. Libson, and J.L. Vanderheyden, 1990. "The Inorganic
Chemistry of Technetium and Rhenium as Relevant to Nuclear Medicine." in: M. Nicolini, G. Bandoli, \& U. Mazzi, Technetium and Rhenium in Chemistry and Nuclear Medicine (pp. 13-20). New York: Raven Press.

10. Setiawan, D., 2010. Sintesis dan karakteristik ${ }^{188}$ Re Hidroksi Apatit untuk Tujuan Radioterapi Kanker. Bandung: Pusat Teknologi Nuklir Bahan dan Radiometri.

11. Hartati, E., D. Setiawan, dan Y.B. Yulitati, 2014. "Sintesis dan Karakterisasi Hidroksi Apatit (HAp) untuk Bahan Pengikat Tungstat dalam Sistem Generator ${ }^{188}$ W/ ${ }^{188}$ Re." dalam: Sains dan Teknologi Nuklir Indonesia, 55-68. 